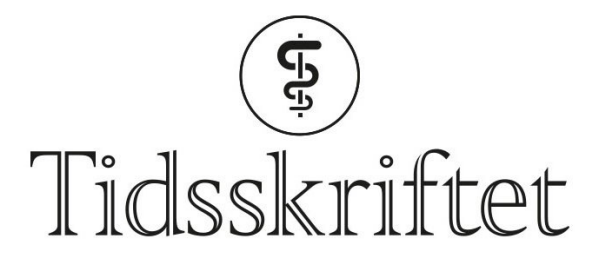

DEN NORSKE LEGEFORENING

\title{
Rehabilitering etter hjerneslag i India
}

FRA ANDRE TIDSSKRIFTER

MATILDE RISOPATRON BERG

Sykehuset Innlandet, Hamar

Kan rehabilitering etter hjerneslag skje i hjemmet med støtte fra et familiemedlem?

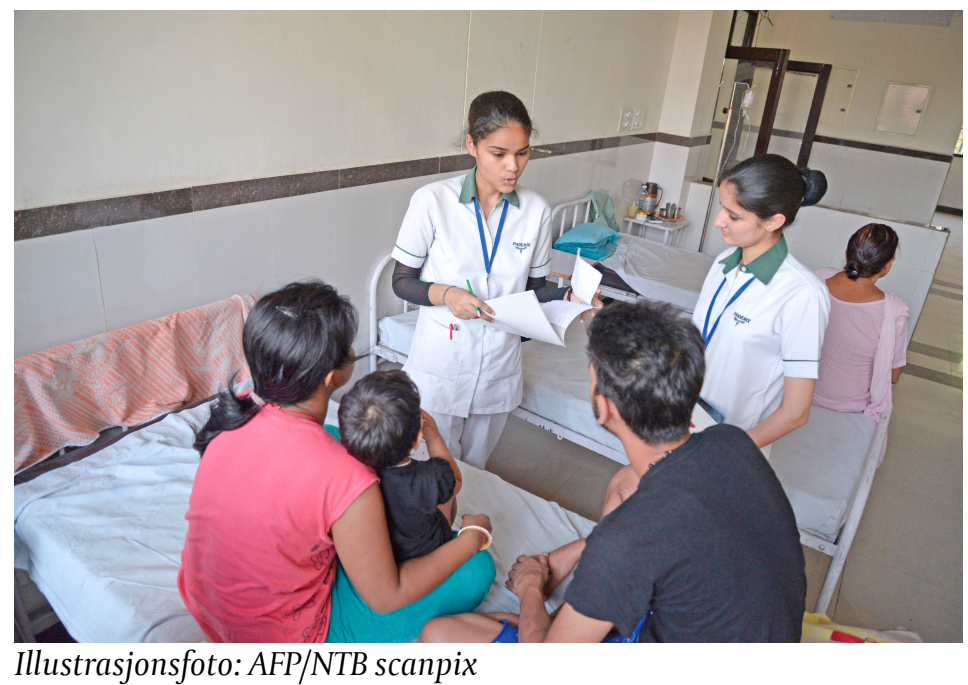

I de fleste lav- og mellominntektsland er tilgang til profesjonell rehabilitering av pasienter med hjerneslag svært begrenset. I en randomisert kontrollert studie i India er det undersøkt om slagpasienter i større grad overlever og blir selvhjulpne ved at familiemedlemmer hjelper til med rehabiliteringstiltak hjemme (1).

1250 voksne pasienter med hjerneslag var inkludert i studien. Slagpasienter som ble vurdert til å ha liten sjanse til å overleve, ble ekskludert. Om lag halvparten av pasientene ble randomisert til rehabiliteringsprogram i hjemmet med støtte av et familiemedlem - i tillegg til standardbehandling. Den andre halvparten ble randomisert til kun standardbehandling.

Rehabiliteringsprogrammet besto av treningsøvelser for å bevare god bevegelighet i ledd og for å klare daglige aktiviteter, slik som påkledning, stell og spising. Opplæringen foregikk én time daglig i tre dager på sykehuset, med oppfølgingsbesøk i hjemmet inntil seks ganger for videre veiledning. Øvelsene skulle utføres med støtte fra et bestemt familiemedlem daglig i opptil to måneder.

Et halvt år etter utskrivning fra sykehus ble det ikke funnet noen signifikante forskjeller mellom de to gruppene. I intervensjonsgruppen var $12 \%$ av pasientene døde, mot $14 \% \mathrm{i}$ kontrollgruppen. Rundt en tredel av pasientene i begge gruppene var fortsatt avhengig av 
hjelp til daglige gjøremål og aktiviteter. Det var heller ingen forskjell $i$ andelen som ble reinnlagt på sykehus.

Studien tyder på at det ikke gir noen helsegevinst å flytte rehabiliteringsoppgaver over til pasienters pårørende, men heller ikke dårligere resultater enn standardbehandlingen i India. Forfatterne etterlyser bedre tilgang til rehabilitering utført av helsepersonell utenfor sykehus.

LITTERATUR:

1. Lindley RI, Anderson CS, Billot L et al. Family-led rehabilitation after stroke in India (ATTEND): a randomised controlled trial. Lancet 2017. [CrossRef]

Publisert: 4. september 2017. Tidsskr Nor Legeforen. DOI: 10.4045/tidsskr.17.0598

(C) Tidsskrift for Den norske legeforening 2020. Lastet ned fra tidsskriftet.no 